\title{
Solitary Kaposi's sarcoma in retromolar region of an HIV positive patient: case report
}

\author{
Sarcoma de Kaposi em região retromolar de um paciente HIV positivo: relato de caso
}

Maiara de Moraes'; Marcelo Gadelha Vasconcelos'; Rodrigo Gadelha Vasconcelos ${ }^{3}$; Rafael Cabral ${ }^{4}$; Igor Lira Gomes ${ }^{5}$; Lélia Maria Guedes de Queiroz ${ }^{6}$

\begin{tabular}{l|l}
\multicolumn{1}{c|}{ key words } & abstract \\
HIV & $\begin{array}{l}\text { Kaposi's sarcoma is a malignant neoplasm of vascular origin. It occurs mainly among immune deficient } \\
\text { individuals, thus it is the most common neoplasm among HIV- positive patients. Its pathogenesis is } \\
\text { complex and has not been fully clarified. This case arouses particular interest due to its anatomic } \\
\text { location in the retromolar region of a 39-year-old male HIV- positive patient, who presented low white } \\
\text { blood cell count and was not undergoing antiretroviral therapy. The emergence of this lesion may be } \\
\text { associated with highly active antiretroviral therapy (HAART) discontinuation and leukopenia. Hence, } \\
\text { the reestablishment of therapy allows a suitable therapeutic approach and contributes to prognosis } \\
\text { and survival rates. }\end{array}$
\end{tabular}

resumo

Sarcoma de Kaposi é uma neoplasia maligna de origem vascular que ocorre principalmente em indivíduos com deficiência imunológica, sendo a neoplasia mais comum em pacientes HIV positivos. Sua patogênese é complexa e não está bem estabelecida. Este caso é de interesse pela localização anatômica em região retromolar de paciente soropositivo, que apresentou baixa contagem de células brancas do sangue e que não realizava terapia antirretroviral. $O$ surgimento da lesão pode estar associado à interrupção da terapia antirretroviral altamente ativa (HAART) è à baixa contagem leucocitária. Assim, o restabelecimento da terapia pode permitir a abordagem terapêutica e contribuir para o prognóstico e a sobrevida.

unitermos

HIV

Sarcoma de Kaposi

Neoplasia

\footnotetext{
1. Mestra em Patologia Oral; doutoranda do programa de Pós-graduação em Patologia Oral da Universidade Federal do Rio Crande do Norte (UFRN).

2. Doutor em Patologia Oral pela UFRN.

3. Mestre em Odontologia; doutorando do Programa de Pós-graduação em Patologia Oral da UFRN.

4. Cirurgião-dentista; especialista em Cirurgia e Traumatologia.

5. Cirurgião-dentista; especialista em Cirurgia e Traumatologia.

6. Doutora; professora da disciplina de Patologia Oral da UFRN.
} 


\section{Introduction}

Kaposi's sarcoma (KS) is a multicentric neoplasm arising from cells of both vascular and lymphatic endothelium and is characterized for proliferation of spindle cells, neoangiogenesis, inflammation and edema ${ }^{(22)}$. It was first described in 1872 by the Hungarian dermatologist, Moritz Kaposi, and has become known as $\mathrm{KS}^{(15,22)}$. The main clinical manifestations appear in the form of macules, plaques and nodules may involve skin, lower extremities, oral cavity and visceral organs. The KS can be subdivided into four types: classic, endemic, iatrogenic and HIV-associated $(\text { HIV-KS) })^{(7,16,22,24)}$.

The association of this tumor with human immunodeficiency virus (HIV) was first described in East Africa. Since then, numerous studies have suggested an association between HIV seropositive patient and the development of $\mathrm{KS}^{(23)}$. After the emergence of antiretroviral therapy (highly active anti-retroviral therapy [HAART]) there was a decline in the appearance of these lesions $\mathbf{s}^{(7,14,23)}$.

$\mathrm{KS}$ is the most common oral neoplasm in patients with the acquired immunodeficiency syndrome ${ }^{(13)}$. Oral HIV-KS most frequently affects the hard palate, the gingival tissues and the dorsum of the tongue. The lesions are either single or multifocal, initially present as bluish-purple to red macules that progress to a papulo-nodular form, and eventually to large exophytic masses ${ }^{(6,7)}$. Presentation of KS in the oral cavity is of great prognostic value as it can be the initial manifestation of generalized KS and the first indication of HIV infection. Additionally, its presence in HIV+ patients signifies higher death rates compared with individuals with cutaneous KS only and it is a prognostic marker for the individual's response to highly active antiretroviral treatment (HAART) $(3,4,10,12)$.

Even with the decline of this tumor, the knowledge of clinical, radiographic and histopathologic features is important to establish an appropriate treatment aimed at a good clinical course and patient cure. This article aims to report a case of KS in unusual location in a HIV positive patient who dropped out of your antiretroviral therapy.

\section{Case report}

A 39 year-old-men, melanoderm, "man who has sex with man" , HIV seropositive for 15 years attended the Oral Diagnosis Service, Department of Dentistry, Federal
University of Rio Grande do Norte (UFRN), complaining of a lesion lasting for two months in the posterior region of the mandible. Intra-oral examination showed a lobulated tumefaction in the mesial of the second pre-molar and molar teeth left with distal involvement of the retromolar region (Figure 1). The lesion was asymptomatic, nonulcerated, reddish-purple, irregular surface, rather fuzzy, firm, exophytic growth, and measuring $3 \mathrm{~cm}$ in its larger diameter. Teeth associated with the injury presented mobility due to previous history of periodontitis. No further lesion in the skin was detected in the body regions. Panoramic radiographic revealed an extensive vertical osseous reabsortion and a rarefaction in the apical region of molar tooth (Figure 2). The laboratorial tests indicated a CD4+ T-cell count below 200 cells $/ \mathrm{mm}^{3}$. The patient had also informed the suspension of antiretroviral therapy for six months. An incisional biopsy was performed based on the hypothesis diagnostic of mucoepidermoid carcinoma. The surgical specimen was fixed in 10\% neutral formalin and submitted to histologic examination. Histologic sections (5- $\mu \mathrm{m}$ thick) were obtained and processed for routine hematoxylin-eosin staining. Histopathological examination showed a nodular and exophytic lesion of the submucosa. The cells tumor exhibit spindle cell ill-defined fascicles with some intervening thin-walled vessels, extravasation of red blood cells and haemosiderin collections. In between, there were found slit-like vessels containing erythrocytes (Figure 3A). The stroma consists of dense connective tissue exhibiting collagen fibers randomly arranged and showing intense vascularization (Figure 3B). Mitoses were rare and so atypical figures were found. Immunostaining was done with anti-CD34 in order to confirm the origin of the endothelial cells lining vascular (Figures 3C and 3D). The definitive diagnosis was KS. The patient had a quiet postoperative course, and at the first week after the biopsy showed signs of tumor growth. The patient was referred to medical oncologist for the completion of treatment. The oncologist suggested the reestablishment of HAART in order to control the progression of KS and to allow immune restoration, since the suppression of viral replication and restoration of immunity by HAART has been effective in tumor control in most patients considered to have a good prognosis. Thus, after the reestablishment of therapy, he may direct an appropriate treatment with control of viral load and leukocyte standard rate and thus determine the therapy for this patient surgical therapy and local radiotherapy. 


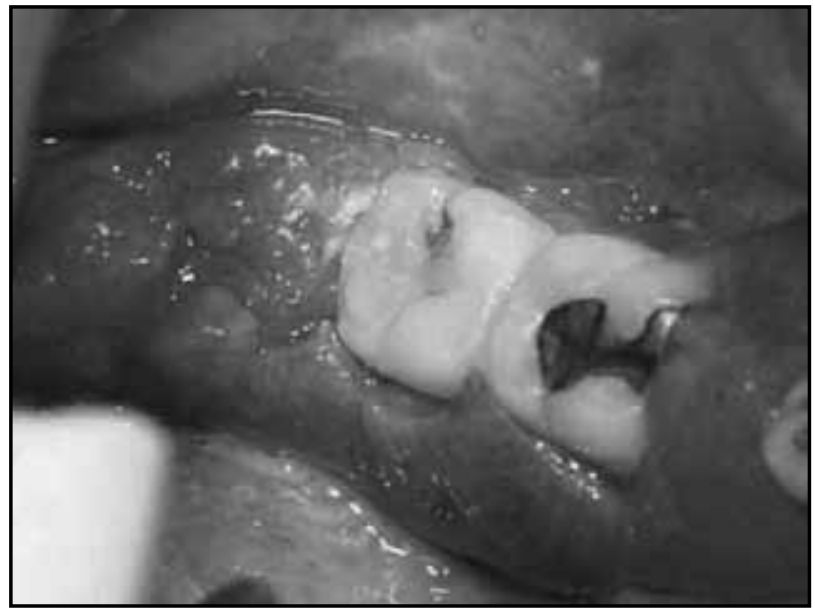

Figure 1 - Exophytic lesion with lobulated area located in retromolar region of the mandible

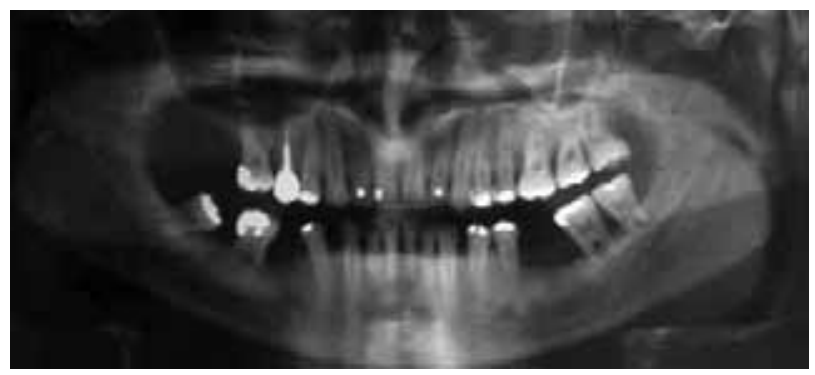

Figure 2 - Panoramic radiograph shows areas of bone resorption of the premolar and molar teeth

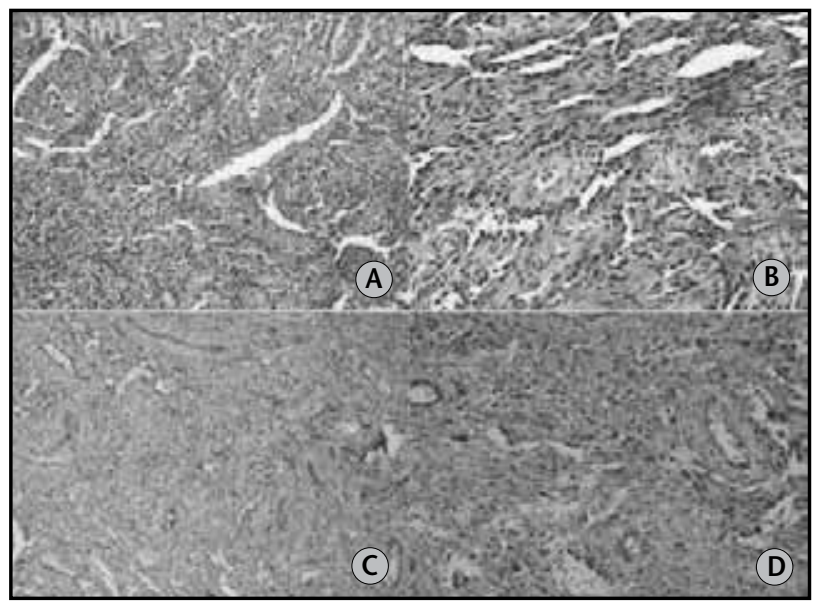

Figure 3 - (A) Cells tumor exhibit spindle cell ill-defined fascicles and extravasation of red blood cells (200x); (B) a proliferation of irregular ill-defined vascular system associated with numerous spindle cells (400x); (C) CD34 immunostaining in tumor cells of KS (LSAB /100x); (D) CD34 immunostaining of endothelial cells lining the blood vessels and spindle cells (LSAB/400x)

$\angle S A B$ : labeled streptavidin biotin.

\section{Discussion}

HIV-associated KS can be pathognomonic for HIV infection and sometimes is the initial manifestation of the disease. In contrast to the classic form of KS, the AIDSrelated form appears very aggressive with multifocal lesions that affect the skin and also the gastrointestinal tract, lungs, mucous membranes and lymphnodes $(3,7,10,13,22)$.

The clinical findings of the current case are in accordance with previous review of cases that have described epidemiological and clinical aspects of AIDS-

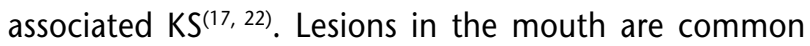
and highly characteristic, occurring particularly on the palate, gum, tongue, and buccal margin, less commonly causing salivary gland swelling and usually in the 30 38 years age group ${ }^{(9)}$. Oral lesions appear as bluish-red our purple macular, papular, or nodular lesions, as in the case presented here, can ulcerate and cause local destruction, may be very uncomfortable but rarely cause frank obstruction $(5,11,14,19)$.

Very rarely cases of primary intraosseous KS of the jaws have also been reported ${ }^{(13,22)}$. In $22 \%$ of subjects with HIV-KS the lesions are first seen in the mouth; and in $71 \%$ of subjects with HIV-KS, sooner or later, the oral cavity will be affected ${ }^{(13)}$. However, our patient presented a starting location rather unusual in the oral cavity associated with a history of periodontitis. The radiographic findings, observed in the case mentioned above, are typical on the periodontal disease. Additionally, no further lesion in the skin was detected in the body regions in the current case.

The histopathological characteristics described for this case are in accordance to the diagnosis criteria established for the SK, according Lamovec and Knuutila ${ }^{(12)}$. SK consists of a significant spindle cells component, and irregular, cleft-like spaces forming new angulated vascular channels containing erythrocytes. In addition, small vessels and spindle cells may be seen protruding into the vascular lumen, these cells could show cytologic atypia. Also, foci of necrosis, and prominent hemosiderin deposits may be present $^{(7)}$.

Ramírez-Amador et al. ${ }^{(18)}$ report that in early stages of KS, it is characterized by a proliferation of small, irregular jagged blood vessels, and an inflammatory lymphocytic infiltrate. A small number of spindle-shaped cells associated with newly-formed vascular spaces, extravasated erythrocytes and hemosiderin deposits may be seen. Hyaline globules are infrequently found. The intermediate stage consists of a significant spindle-shaped cells component, and irregular, cleft-like spaces forming new angulated vascular channels containing erythrocytes, corroborating our findings. In addition, hemosiderin deposits and hyaline globules may be observed. The late stage entails intersecting sheets and 
fascicles of uniform spindle-shaped cells forming slit-like vascular spaces; small vessels and spindle-shaped cells may be seen protruding into the vascular lumen, these cells could show cytologic atypia.

KS is constituted by a heterogeneous cell population, with the predominant spindle cells expressing endothelium, monocyte-macrophages, fibroblasts and smooth muscle markers. The possibility of blood vascular endothelial lineage as the source for spindle-cell, has been raised based on the positive results to CD-34, CD31, CD40, factor VIII-related antigen, smooth muscle cell markers, macrophage marker (CD68), and dendritic cell marker $(\mathrm{CD} 14)^{(7,12,13,16)}$. On the other hand, as initially proposed by Beckstead et al. ${ }^{(2)}$, immunohistochemical and molecular studies have sustained that spindle-cell in KS arise from lymphatic endothelium. However, it is still an intriguing aspect whether these cells derive from blood or lymphatic endothelium ${ }^{(7)}$. Furthermore, it has been considered that $\mathrm{KS}$ is originated from endothelial cells, as confirmed in this study by the positivity to CD34; it has been suggested that $\mathrm{KS}$ is derived from a heterogeneous hybrid population, including mesenchymal precursors, possibly endothelial progenitor cells ${ }^{(7)}$.

Therapeutic options for KS consider the type of KS, the disease stage, the progression pattern, the lesion location and size and immune status(23). A variety of therapeutic options exist, including surgical excision, surgical ablation, intralesional interferon alpha- $2 \beta$, local or extended field radiotherapy, and chemotherapy. As KS may involve every tissue of the human body, the surgical approach is limited to diagnostic biopsy or even removal of small tumors, and it is considered palliative. For patients with rapid evolution, chemotherapy is recommended ${ }^{(1)}$.

In the presented case, surgical removal, radiotherapy, and reestablishment of antiretroviral therapy were the treatment options used. The good response was considered a positive marker for the patient's future outcome, as in addition to the increasing CD4+ T-cell count it indicated the improvement of the immune system. After a year without evidence of recurrence, the patient remains under follow up.

The introduction of HAART in 1996 has greatly influenced the pattern of KS incidence in people with HIV. The decrease in the prevalence of severe immunodeficiency has resulted in a rapid reduction in KS. In recent studies, Franceschi et al. ${ }^{\left({ }^{(8)}\right.}$ found decreased of incidence of KS by several fold between the pre- and early-HAART periods, and additionally declined from the early- to the late-HAART period. Seaberg et al. ${ }^{(21)}$ found 514 cases of HIV-KS in the pre-HAART and 38 cases in the HAART-era, the incidence was significantly reduced. Schwartz et al. ${ }^{(20)}$ point out that KS was a malignant neoplasm that is often progressive largely spreading to the lymph nodes and several organs. The HAART therapy with protease inhibitors has been associated with a reduction of $30 \%$ to $50 \%$ in the prevalence of $\mathrm{SK}^{(20)}$.

When KS develops in patients on HAART, it seems to exhibit a less aggressive clinical pattern. The 3-year survival rate was $64 \%$ with KS-HAART patients as compared with $78 \%$ without HAART ${ }^{(6)}$. The improvement in the clinical course of HIV-KS following HAART is associated with three factors. The first is that there is a reduction in HIV load with a consequent improvement in the host-immune status. Second, there is an improvement in the HHV-8 specific cytotoxic CD8+ T-cell responses, resulting in a decreased $\mathrm{HHV}-8$ viral load, and a reduction in the HHV-8 and HIV-induced inflammatory cytokines. The third factor is that the protease inhibitors have a direct antiangiogenic effect ${ }^{(5,12)}$.

It is evident that in the majority of subjects who are HIV seropositive with KS, effective HAART decreases the incidence and the prevalence of $\mathrm{KS}$ and causes regression of established lesions. However, in a small subset of subjects who are HIV seropositive, effective HAART leads paradoxically to the resurgence of HIV-KS. The mechanism of this is not fully understood ${ }^{(12,13)}$. In the present case, the abandonment of antiretroviral therapy culminated with the appearance of the lesion.

\section{Conclusion}

In conclusion, in the present study, we have described the case of HIV associated-KS. Follow-up of this cases are usually performed along with HIV routine exams. In isolated cases, tumor progression can occur despite CD4+ lymphocytes over $400 \mu \mathrm{l}$ and a low viral load. Therefore, examination of the skin and mucous membranes, the lung (chest X-ray) and the gastrointestinal tract (occult blood, sonography, perhapsendoscopy) every 6-12 months are recommended. 


\section{References}

1. ABLASHI, D. V. et al. Spectrum of Kaposi's sarcomaassociated herpesvirus, or human herpesvirus 8, diseases. Clin Microbial Rev, v. 15, n. 3, p. 439-64, 2002.

2. BECKSTEAD, J. H.; WOOD, G. S.; FLETCHER V. Evidence for the origin of Kaposi's sarcoma from lymphatic endothelium. Am J Pathol, v. 119, n. 2, p. 294-300, 1985.

3. CAMPO-TRAPERO, J. et al. Relationship between oral Kaposi s sarcoma and HAART: contribution of two case reports. Med Oral Patol Oral Cir Bucal, v. 13, n. 11, p.709-13, 2008.

4. CATTELAN, A. M. et al. Long-term clinical outcome of AIDS-related Kaposi's sarcoma during highly active antiretroviral therapy. Int J Oncol, v. 27, n. 3, p. 77985, 2005.

5. EPSTEIN, J. B.; CABAY, R. J.; GLICK, M. Oral malignancies in HIV disease: changes in disease presentation, increasing understanding of molecular pathogenesis, and current management. Oral Surg Oral Med Oral Pathol Oral Radiol Endod, v. 100, n. 5, p. 571-8, 2005.

6. FELLER, L. et al. Human immunodeficiency virusassociated Kaposi sarcoma as an immune reconstitution inflammatory syndrome: a literature review and case report. J Periodontol, v. 79, n. 2, p. 362-8, 2008.

7. FELLER, L.; WOOD, N. H.; LEMMER, J. HIV-associated Kaposi sarcoma: pathogenic mechanisms. Oral Surg Oral Med Oral Pathol Oral Radiol Endod, v. 104, n. 4, p. 521-9, 2007.

8. FRANCESCHI, S. et al. Changing patterns of cancer incidence in the early- and late-HAART periods: the Swiss HIV Cohort Study. British Journal of Cancer, v. 103, p. 416-22, 2010.

9. HAUERSTOCK, D.; GERSTEIN, W.; VUONG, T. Results of radiation therapy for treatment of classic Kaposi sarcoma. J Cutan Med Surg, v. 13, n. 1, p. 18-21, 2009.

10. JESSOP, S. HIV-associated Kaposis sarcoma. Dermatol Clin, v. 24, n. 4, p. 509-20, 2006.

11. KALPIDIS, C. D. R. et al. Gingival involvement in a case series of patients with acquired immunodeficiency syndrome related Kaposi sarcoma. J Periodontol, v. 77, n. 3, p. 523-33, 2006.

12. LAMOVEC, J.; KNUUTILA, S. Kaposi sarcoma. In: FLETCHER, C. D. M.; UNNI, K. K.; MERTENS, F. (Ed.) World Health Organization classification of tumours.
Pathology and genetics of tumours of soft tissue and bone. Lyon: IARC Press, 2002. p. 170-2.

13. LAUSTEN, L. L. et al. Oral Kaposi's sarcoma associated with severe alveolar bone loss: case report and review of the literature. J Periodontol, v. 74, n. 11, p. 1668-75, 2003.

14. NOY, A. Update in Kaposi sarcoma. Curr Opin Oncol, v. 15, n. 5, p. 379-81, 2003.

15. OJI, C.; CHUKWUNEKE, F. Clinical evaluation of Kaposi sarcoma in HIV/AIDS patients with orofacial lesions in Enugu, Nigeria. J Oral Maxillofac Surg, v. 66, n. 7, p. 1362-5, 2008.

16. PAPAGATSIA, Z. et al. Oral Kaposi sarcoma: a case of immune reconstitution inflammatory syndrome. Oral Surg Oral Med Oral Pathol Oral Radiol Endod, v. 108, n. 1, p. 70-5, 2009.

17. RAMÍREZ-AMADOR, V. et al. Clinical, histological and immunohistochemical findings in oral Kaposis sarcoma in a series of Mexican AIDS patients. Comparative study. J Oral Pathol Med, v. 38, n. 4, p. 328-33, 2009.

18. RAMÍREZ-AMADOR, V.; ANAYA-SAAVEDRA, G.; MARTINEZ-MATA, G. Kaposi's sarcoma of the head and neck: a review. Oral Oncol, v. 46, n. 3, p. 135-45, 2010.

19. REICHART, P. A.; KHONG, K. P.; BENDICK, C. Oral manifestations in HIV-infected individuals from Thailand and Cambodia. Med Microbiol Immunol, v. 192, n. 3, p. 157-60, 2003.

20. SCHWARTZ, R. A. Kaposis sarcoma: an update. J Surg Oncol, v. 87, n.3, p. 146-51, 2004.

21. SEABERG, E. C. et al. Cancer incidence in the Multicenter AIDS Cohort Study Before and During the HAART Era. Cancer, v. 15, n. 23, p. 5507-16, 2010.

22. VAN DER WAALL, I.; LAMOVEC, J.; KNUUTILA, S. Tumours of the oral cavity and oropharynx In: BARNES, L. et al. World Health Organization classification of tumours. Pathology and genetics head and neck tumours. Lyon: IARC Press, 2005. p. 195-6.

23. WAMBURU, G. et al. HIV-associated and non-HIV associated types of Kaposi's sarcoma in an African population in Tanzania. Status of immune suppression and HHV-8 seroprevalence. Eur J Dermatol, v. 16, n. 6, p. 677-82, 2006.

24. WANG, X. et al. Classic Kaposis sarcoma in Han Chinese and useful tools for differential diagnosis. Oral Oncol, v. 46, n. 9, p. 654-6, 2010.

\begin{tabular}{l|l} 
& Mailing address \\
\hline Maiara de Moraes \\
Universidade Federal do Rio Grande do Norte \\
Departamento de Odontologia \\
Av. Senador Salgado Filho, 1.787 - Lagoa Nova \\
CEP: 59056-000 - Natal-RN \\
Tel./fax: (84) 3215-4138 \\
e-mail: maiaramoraes@gmail.com
\end{tabular}

